\title{
After Public Law
}

Eds. Cormac MacAmlaigh, Claudio Michelon, Neil Walker

Oxford University Press, 2013

PART THREE

THE EVOLUTION OF PUBLIC LAW? 


\title{
$<$ new recto $>$
}

\section{Globalization and the Transcendence of the}

\author{
Public/Private Divide — What is Public Law under
}

Conditions of Globalization?

\author{
Inger-Johanne Sand
}

\section{Introduction-What is Public Law in Global and Risk Society?}

Public law as an institution and as a way of thinking in law has a long and highly differentiated history. In its present form, in modern democratic nation-states, public law is inherently a part of the tradition of the nation-state and its related concepts such as sovereignty, democracy, freedom rights, constitutionalism, the principle of legality, and public government and administration. Public law is unavoidably also an ambiguous and paradoxical concept; it is law by the people, for the people. 'The people' are the subject and the object of public law, its author and addressee. Public law is part of the interdependent 
relationship between politics and law, and between democracy and individual rights. Public law can also be seen as the crucial regulatory and normative link between the 'force' of the state and the freedom and rights of its citizens. Public law endows rights and guarantees freedom, but also regulates the use of force and administrative power which can be used both for and against citizens. Modern public law requires authority, the voice and participation of the people, and contextual knowledge and reflexivity.

Public law is both the structure and a necessary dynamic of change and variation in society. It includes both the administrative and regulatory law of a variety of social and technical fields and the more exceptional uses of force. It has been the expression of 'the general will' and of the sovereign, but has over time been transformed to more pluralistic, democratic, diverse, open, and dynamic forms. It conveys social values, but also technocratic and bureaucratic forms. Public administration has become more varied and polycentric than before, both in its organizational forms and its substance. In relation to the citizens, it has traditionally been the law of the nation-states but increasingly includes European (or other regional) law and public international law. Both on the domestic and the international levels, many public administrative agencies are more like expert bureaucracies than democratically controlled organizations. Public administration increasingly involves not only the rule of law and public regulatory law but also contract and competition law mechanisms thus transcending the public/private law boundary and becoming increasingly diverse in its modes of operation. Public law has thus expanded its scope to include an increasing number of 
social, knowledge-based, and technological areas and is at the same time blurring the boundaries between state and society. ${ }^{1}$

Over time public law has developed procedural and substantive principles which have been vital in securing the legitimacy of modern democratic and rule-of-law states. Legality, fundamental rights, rule-of-law procedures, transparency, reasonableness, various forms of justice, and judicial review are examples of principles expressed in modern public law. ${ }^{2}$ Within these principles are contained both important values for the functioning of an open society but also contradictions, differences and ambiguities related to the dualities of the rule of law and democracy, justice, efficiency, and the performance and limitations of power. The continuous evolution of public law is occurring within the dynamics of the ambiguities and differences of the principles of public law and at the same time challenging some of its main values.

The public law of modern states has evolved historically and expanded from rule-of-law and penal law orientations to ambitious administrative regulation of a wide range of important social issues. In the first phase of modernity, public law evolved to incorporate fundamental constitutional rights and the development of institutions, procedural legality, and criminal law. With industrialization and urbanization areas of substantive public and administrative law evolved, such as welfare law, labour law, economic regulatory law, and zoning and

\footnotetext{
${ }^{1}$ Helmut Willke, 'The tragedy of the state' (1986) Archiv für recht- und Sozialphilosophie 455.

${ }^{2} \mathrm{Ch} 2$, this book.
} 
building law. From the 1960s and 1970s onwards, new challenges of modernity had evolved and new and more ambitious public regulatory law emerged such as more ambitious forms of welfare law, environmental protection, industrial protection, and gender equality, to name but a few. Public law had become a vital and active instrument of political and social reform and created new social structures and institutions. By the 1980s, more liberal economic regulation, with an emphasis on competition law but also spreading to many other fields, emerged, as well as more detailed regulations of specific issues and new technologies. Regulations ensuring free movement and competition law have created significant forms of interconnection and interdependencies between public and private law and the economy, and also between individual rights and regulatory regimes. A more liberal economic regime has been implemented through public law. Increasingly extensive and intensive uses of new technologies leading to what has been labelled 'the risk society' have also been regulated through public law notwithstanding significant uncertain and, at times, unpredictable consequences. ${ }^{3}$ Public law is, then, increasingly regulating the future with significant uncertainty, and in tandem with continuously changing technologies.

\footnotetext{
${ }^{3}$ Gunther Teubner, 'Reflexives Recht', (1982) vol. LXVIII no. 1 Archiv für Recht- und Sozialphilosophie 13 et seq; Duncan Kennedy, 'Three globalizations of law and legal thought: 1850-2000', in The New Law and Legal Development, David Trubek and Alvaro Santos (eds), (Cambridge: Cambridge University Press, 2006); Helmuth Willke, Die Ironie des Staates, (Frankfurt: Suhrkamp, 1992); Niklas Luhmann, Risk: A Sociological Theory, (Berlin: de Gruyter, 1993).
} 
Various social, economic, technological, and political changes are currently affecting the preconditions and the operations of both governance and government in general, and of public law with significant effects on its procedures, principles, and substance. First of all, the number of international organizations, treaties, and dispute-settlement bodies and courts have increased significantly over the last fifty years, as well as the effects of law produced by these actors. A significant part of public law is now produced or at least initiated by international organizations and negotiations as public international law. The people behind public international law, and its interests, are heterogeneous in a very different way than the people of a nation-state. The quality and the forms of democratic procedures are different than those on a national level. In this way, the procedures and the context of the production of public law have changed significantly. Secondly, on the international level public law appears fragmented and asymmetric, regulated on a treaty-by-treaty basis, and is thus quite different from the more harmonized and balancing forms of domestic public law. Thirdly, public law has expanded to regulate an increasing number of areas, many of which are discursively dominated by highly specialized knowledge and technologies. Law tends to become parasitic on other codes and rationalities in ways which may affect legal rationality and principles. The regulation of highly specialized technologies also implies the evaluation of risk. Fourthly, legal areas and mechanisms which traditionally have been labelled as either public or private law, such as public regulation, rights, and contracts, have increasingly become more interconnected and interdependent, and thus less distinctive from each other. Rights have 
become an increasingly vital part of public regulation and are in many ways part of both public and private law. Public agencies use contracts, corporations, and competition. Private actors increasingly regulate their activities through a variety of norms and guidelines. NGOs have become an increasingly significant part of public life and public regulation.

The changes referred to earlier are influencing to a significant extent many of the characteristics of public law as it has emerged in modern democratic nation-states. Public law is currently emerging in a more polycontextural and pluralistic landscape than in the era dominated by the nation-state. It is the expression of several institutions, of national as well as international levels of government, and of various forms of interaction between public and private actors, reflecting the dispersion of sovereignty and the distribution of public tasks in society. There is thus a substantive differentiation in, and an expansion of, public law and the institutions involved, which impacts concepts such as 'the general will', 'the common good', and the balancing of various public interests and considerations. This, in turn, may affect the understanding of legitimacy. Furthermore, public law refers to an increasing number of substantively quite different regulatory discourses, many of them highly specialized and part of new technologies. This substantive expansion contributes to the further differentiation of public law. Public and private law principles and standards are also becoming increasingly interconnected. Contract law and individual rights are increasingly influential parts of public law, and are thus also changing both the configuration and principles of public law. Still, many of the procedural and substantive principles and values of modern public law remain. 
Another qualitative change concerns the globalization of social and economic dynamics, but with insufficient political, legal, and democratic procedures and institutions in place, and thus an uncertainty as to how 'the common good' is to be understood and interpreted. This chapter will explore some of these changes in the evolution and the understanding of public law illustrated by specific examples.

\section{Public/Private Law Boundaries and the Differentiation and Globalization of Society}

Public law retains a vital role in modern societies, but what it regulates, how, and by whom have all undergone significant change. The preconditions, function, and forms of public law have changed inter alia due to a number of factors. First of all there are processes of functional and communicative differentiation in society leading to an increasing social differentiation and specialization in the areas regulated by public law. ${ }^{4}$ The high degrees of differentiation and specialization of the scientific and economic systems and their semantics have led to equivalent forms of specialization of the sub-systems and semantics of law. The specialization of economic and scientific communications will additionally tend to lead to

\footnotetext{
${ }^{4}$ Niklas Luhmann, The Differentiation of Society, (New York: Columbia University Press, 1981); Niklas Luhmann, Das Recht der Gesellschaft, (Frankfurt: Suhrkamp, 1993) chs 11-12; Niklas Luhmann, 'The Modern Sciences and Phenomenology', in Theories of Distinction, Michael Rasch (ed.), (Stanford: Stanford University Press, 2002).
} 
resistance to political and legal forms of regulation. Law willcreate structural or organizational couplings with other function systems and their semantics leading to the transferring of such semantics into law and combining them with legal concepts and regulatory forms. Public law will increasingly emerge as a variety of differentiated sectors or themes with their distinct logics and semantics, and less as an expression of a 'whole' society with unified consensus of the balancing between the different logics, values and interests. This is further emphasized by the fragmented character of international law. The definition of the 'general will' will then increasingly depend on processes and discourses within the different and specific sectors and their institutions previous to or as part of legal regulations, and will be less influenced by consensual and general discourses of the 'common good' of society. The increasing specialization within the different sectors or areas will tend towards sector-specific regulations and to more difficult processes of balancing between the different discourses and values. Dependence on sector-specific discourses and semantics will question the existence of a 'general' will.

Moreover, and connected to the preceding development, there has been a general expansion of law in most social areas. This expansion of law occurs on several levels of law: it includes public regulatory law, the use of contracts, trade law, and free movement of goods, services, persons, and capital, and human rights, which often are applied in connection with each other. The expansion of law may thus create more intensive couplings between the different forms of public law and private law, the transcendence of their boundaries, and more 
intensive forms of legalization. The expansion of law, and its regulation of new technologies, has also led to the legal regulation of areas which previously have been seen as private or personal, or as professionally regulated by technical standards and guidelines. Notable examples include the more detailed regulations of health services, the use of medical biotechnologies, in particular the use of reproductive techniques and prenatal tests, and childparent relations, as well as social welfare benefits and services. The uses of new technologies have led to public regulation at the boundaries between public and private law or transcending the distinction altogether. The expansion of rights paradoxically often leads to more detailed public regulations in order to implement and secure the rights. One example is the right to non-discrimination which can be quite complex to define and adjudicate as it often sits on the balance between quite different public and private values, such as freedom-of-expression and various forms of social protection. The changes from a more macro- to a more micro- and market-oriented focus in economic public discourses has also led to an increasing interweaving between public and private economic dynamics. Free movement, rights, markets, and competition are primary institutions of a liberal economy, but are also intensively legally and publicly regulated with a market-oriented regulatory focus. ${ }^{5}$

Most social areas are regulated by public legislation and often controlled in different ways by public agencies. Public and private law thus increasingly interact horizontally across society. Many areas are regulated by both public law and private contracts and organized by

\footnotetext{
${ }^{5}$ See among the many texts on this: Constitutionalism, Multilevel Trade, Governance and Social Regulation, Christian Joerges and Ernst-Ulrich Petersmann (eds), (Oxford: Hart, 2006).
} 
both public agencies and private corporations. Public and private law combine and interact in a variety of different ways. They depend on and use each other. They combine but also compete. Institutional and legal couplings, such as privatization of public utilities, stateowned corporations, and competition law evolve in the interface between public and private law and their respective values. The same standards of economic efficiency often apply in both spheres.

Furthermore, there is an expansion of law also on the inter-and transnational levels with a corresponding institutional architecture, including courts, in areas which previously have been primarily regulated on the domestic and nation-state level. ${ }^{6}$ International treaties increasingly regulate trade, competition, the environment, climate, labour, and human rights law with direct or indirect effects. International trade and competition law are regulatory regimes with significant effects, both procedural and substantive, on public and administrative law at the international and domestic levels. There is a greater variety of political and legal institutions involved in the legislative, administrative, and adjudicative processes. The legal structures of the EU and WTO, in particular, with their preference for and focus on free movement and liberal trade and competition as law and policy goals have had significant effects on other areas of domestic law and on the structure, goals, and principles of public

\footnotetext{
${ }^{6}$ Saskia Sassen, Territories, Authorities, Rights (Princeton: Princeton University Press, 2006); Andreas Fischer-Lescano, 'Globalverfassung: Verfassung der Weltgesellschaft' (2002) Archiv für Recht- und Sozialphilosophie ; Gunther Teubner, Constitutional Fragments. Societal Constitutionalism and Globalization, (Oxford: Oxford University Press, 2012).
} 
law. ${ }^{7}$ Economic and market-oriented law has become an increasingly vital part of public law. The internationalization of law has led to complex and interdependent multi-level institutional systems and has had significant effects on the structure and the institutions of public law.

Finally, new forms of law have evolved. Self-regulation and other more autonomous forms are increasingly applied and may be seen as lying on the boundary between public and private law or as qualitatively new legal forms. ${ }^{8}$ Public legislation frequently delegates the implementation of law in some areas to self-regulatory mechanisms and more distanced forms of public control. Moreover, the expansion and differentiation of law has also led to various forms of inclusion of citizens and non-public actors and organizations in the various processes connected to public regulation. Forms of self-regulation, consumer rights and patient rights are examples.

Some areas develop organizations and institutions of their own for the implementation of regulatory decision-making and controll, as part of public agencies, privately organized, or organized by sector. In some cases international institutions or agencies are developed to standardize, harmonize, or regulate highly specialized areas. One well-known example is the

\footnotetext{
${ }^{7}$ Joseph H. H. Weiler, (ed.), The EU, the WTO, and the NAFTA: towards a common law of international trade, (Oxford: Oxford University Press, 2000); Christian Joerges and Ellen Vos (eds), EU Committees: Social Regulation, Law and Politics, (Oxford: Hart, 1999); Anne-Marie Slaughter, A New World Order (Princeton: Princeton University Press, 2004).

${ }^{8}$ See examples in Christian Joerges, Inger-Johanne Sand, and Gunther Teubner (eds), Transnational Governance and Constitutionalism, (Oxford: Hart, 2004); Gunther Teubner and Andreas FischerLescano, 'Regime-Collisions: The Vain Search for Legal Unity in the Fragmentation of International Law' (2004) 25 Michigan Journal of International Law 999; Gunther Teubner, Constitutional Fragments. Societal Constitutionalism and Globalization.
} 
Internet Corporation for Assigned Names and Numbers (ICANN), but other examples include UN-based agencies such as the Codex Alimentarius of the FAO/WHO, the UNHCR, and the WTO. ${ }^{9}$ Self-regulatory mechanisms are used by both public institutions and private organizations. Regulatory and semantic resistance from highly specialized areas can be a well-known problem for public regulatory law. This problem has become more urgent in scope and intensity because the different areas have become increasingly specialized, and thus internally defined, communicatively as well as normatively. A vital problem is how to develop legal concepts, standards, and procedures which include a wider societal scope, also adressing the various negative side-effects and consequences of new technologies, including relevant ethical problems.

The societal, institutional, and communicative changes referred to contribute to changes in how we perceive of society and of what society is, including how we perceive of the concepts of the public, the state, civil society, the interfaces between the public and private and between the state and civil society, and how we manage or choose to regulate society. Society and the 'public' have become functionally and communicatively differentiated with significant consequences for public law, for the definition of the common good, and the evolution of social practices and norms including legal norms. With the expansion of rights in general and in particular of human rights, public and private law mechanisms and concepts have become increasingly interconnected and interdependent. The differentiation of the

\footnotetext{
${ }^{9}$ See note 8 .
} 
economy has created new interactions and interdependencies between public budgets and markets. New technologies and knowledge create new institutions in society and diversify how power is dispersed. Technologies and knowledge are public dynamics, but also intervene in people's private lives. They contribute significantly to the transcendence of the distinctions between public and private spheres. Public law is not only about controlling the power of the state, but also about controlling the power of a variety of new technologies, with highly structuring, enabling, and potentially coercive qualities. ${ }^{10}$

The globalization of many social, cultural, and economic dynamics will mean that many societal dynamics will evolve at the same time on several institutional and territorial levels which are intensely interconnected and interdependent. ${ }^{11}$ On the different institutional and organizational levels, the social dynamics refer to different conceptions of society and different cultural and value preferences. The public law of such cross-boundary strata and frontier zones will have to deal with the multi-levelled social context of both legislation and adjudication, and with the pressure to harmonize even across different social contexts. Public law emerges on domestic, regional, international, and transnational levels according to different procedures and different forms of democratic or other forms of decision-making. In some cases there will be institutional harmonization, in other cases differences will be upheld.

\footnotetext{
${ }^{10}$ Gunther Teubner, 'Societal Constitutionalism', in Transnational Governance and constitutionalism, .

${ }^{11}$ Joseph H. H. Weiler, The Constitution of Europe, (Cambridge: Cambridge University Press, 1999); Teubner and Fischer-Lescano, 'Regime-Collisions'; Slaughter, A New World Order ; Sassen, Territories, Authorities, Rights.
} 
Semantic and normative patterns which develop with high degrees of autonomy, such as in specialized technologies, may show resistance to open regulatory democratic processes.

Forms of democracy practiced on the level of the nation-state are clearly insufficient for many of the regulatory challenges of public law. Global or international institutions are, on the other hand, also insufficiently developed in democratic terms. The consequences of these changes for public law are diverse, still very much in progress and difficult to sufficiently describe and analyse at this stage. In the ensuing section I will analyse some examples and aspects of these changes.

\section{Four Examples of New Public Global and International}

\section{Law}

\subsection{International and European economic law as a differentiation of public/private law}

The free movement of goods, persons, services, and capital, and competition law of the EU are public regulatory law, and are at the same time, and equally vital, organizing the relations between private actors and guaranteeing rights. These regulations illustrate both the differentiation of public law and the close interaction between public and private law. In the $\mathrm{EC}$ and EU treaties, economic regulations with the purposes of creating a common market 
among the member states and more efficient competition with heavier restrictions on state subsidies have been the primary regulatory goals. From the late 1970s this also coincided with a more general monetary, micro-economic, and market orientation in economic policies. Compared with the member-states' more general regulatory systems, the EU treaties and case law contained a more specific economic legislation. In EU law economic and market-oriented goals have been more fully developed and given preferential treatment compared to other regulatory goals. The free movement of goods, persons, services, and capital, and competition law are seen as the most fundamental norms and equivalent principles of Community legislation and are its most fully developed areas of regulation. Social, environmental, and other regulations are treated as exceptions which require strict justification. ${ }^{12}$ These regulatory patterns have been developed in order to ensure an effective implementation of free movement and competition. Exceptions are accepted when they are based on objective and non-discriminatory criteria, deemed necessary and proportionate in order to implement accepted public policy objectives, are applied non-arbitrarily and according to procedures which are easily accessible and transparent. ${ }^{13}$ Social and environmental protection are to be accorded a high level of protection, but they must not violate or infringe upon the economic regulatory goals. ECJ case law such as Watts, Laval, and Viking, among others, allows for a

\footnotetext{
${ }^{12}$ Case C-341/05 Laval un Partneri Ltd. v Svenska Byggnadsarbetareförbundet and Others [2007] ECR I-11767 para 87, 101 flw.

${ }^{13}$ Case C-372/04 The Queen, on the application of: Yvonne Watts. v Bedford Primary Care Trust and Secretary of State for Health [2006] ECR I-04325 para 116; Laval para 91 flw.
} 
high level of protection of non-economic goals; however, the decisions illustrate how the economic goals of free movement receive the primary protection under EU law. ${ }^{14}$ In Laval, the court accepted that the right to collective bargaining may be a fundamental right, but it can only be exercised subject to certain restrictions and must be reconciled with the requirements relating to rights protected under the EU treaty, such as the free movement of persons and services. ${ }^{15}$

The ECJ have developed highly specialized and precise semantics and patterns of argumentation concerning the interpretation of free movement and the standards of nondiscrimination in relation to other goals. ${ }^{16}$ This is clearly within the remit of public law, but it differentiates public law by creating a particular regulatory scheme of economic law under the standards of free movement and competition law with an effective ban on state subsidies, including on public services. Free movement of goods, services, persons, and capital are seen as rights under the treaties to be fully protected. Other types of rights can also be seen as parts of the general principles of the EU treaties, but are protected in compliance with economic

\footnotetext{
${ }^{14}$ Case C-438/05 International Transport Workers' Federation and Finnish Seamen's Union v Viking Line ABP and Ö̈ Viking Line Eesti [2007] ECR I-10779.

${ }^{15}$ Laval paras 91-96.

${ }^{16}$ Cf Case 24/68 Commission v Italy [1969] ECR 193; Case 8/74 Procureur du Roi v Dassonville [1974] ECR 837; Case 120/78 Cassis de Dijon [1979] ECR 649; Case C-267/91 and C-268/91 Keck and Mithouard [1993] ECR I-6097; Joseph H. H. Weiler, 'The Constitution of the Common Market Place: Text and Context in the Evolution of the Free Movement of Goods', in The Evolution of EU Law, Paul Craig and Gráinne de Búrca (eds), (Oxford: Oxford University Press, 1999); Christian Joerges, 'Free trade: the erosion of national and the birth of transnational governance' (2005) 13 European Review 93.
} 
freedoms. EU public law is a particular legal regime with enumerated competences and not a fully comprehensive legal regime subject to the general will of the people with a general balancing of different regulatory goals. WTO economic law shares many of the general characteristics of regulatory specification and delimitation of EU law, but with differences in the specific forms for regulation and with a lack of harmonization. WTO law is a more economically specific legal regime than the EU. The environmental and health protections of the General Agreement on Tariffs and Trade (GATT) Art. XX and the Agreement on the Application of Sanitary and Phyto-Sanitary Measures (SPS) are clearly insufficient as protective regulations in themselves.

The lessons so far from the legislation and the case law of the free movement of the EU and of the WTO is that it has been easier to develop the economically based free-movement regulations effectively, than to establish standards for the protection of the environment, health, and social rights. Effective markets and competition have so far been given preferential treatment. Environmental and health protection are subject to the demands of scientific evidence for hazards and for protective measures. Precaution is applied pursuant to the demands for scientific evidence. Sustainability and ethical considerations are still underdeveloped, legally speaking. ${ }^{17}$

\footnotetext{
${ }^{17}$ Oren Perez, Ecological Sensitivity and Global Legal Pluralism, (Oxford: Hart, 2004) chs 3-4.
} 


\subsection{New interfaces between public and private economic and}

\section{administrative law}

Also within the domestic public regulatory regimes of democratic nation-states there are many signs of an increased differentiation, specialization, and market-orientation of public law and economic regulations with an increased focus on the uses of markets, competition, and economic efficiency both in public regulations and in state agencies. Macro-oriented and planning law instruments have been replaced by competition, benchmarking, privatization, and deregulation. The latter instruments enable an increased autonomy and specialization of the economic ends both within themselves and in relation to other policy goals. The insistence on economic efficiency and the use of competition as regulatory mechanisms leads to clearer distinctions between economic and other policies and regulatory goals. Public agencies have also become more clearly separated into different types of agencies depending on whether their functions are policy-oriented, performing/producing, regulatory, or controlling.

In Norwegian public law, for example, there has been an immense increase in the use of contracts and other market-, and competition-oriented regulatory mechanisms as part of public regulatory regimes. ${ }^{18}$ Competition has become an increasingly vital standard and regulatory mechanism applied in public regulation and the further organization of the public

\footnotetext{
${ }^{18}$ Inger-Johanne Sand, 'Changes in the organization of public administration and in the relations between the public and the private sectors. Consequences of the evolution of Europeanisation, globalisation and risk society', ARENA working-paper no. 2/2002.
} 
sector. Examples include the requirement for a certain return rate on all public investments, even if they are for the general good, the use of public procurement, benchmarking, privatization, and the use of competition as an internal standard. When the OECD in 2003 reported on the status of Norwegian public administration, the main concern of the evaluation was to what degree and how the various public sectors applied 'competition', benchmarking, public procurement etc.

State-owned corporations, wholly or partially owned, are used for public services, communications, energy production, and other policy areas, such as telecommunications, and oil and gas production. Because of the more general history of the use of state corporations in Norway, particularly with regard to hydroelectricity and oil and gas production, Norway has a large number of state-owned corporations. They are run as autonomous corporations on market terms. The three largest corporations in Norway today are partially state owned, the two largest with a clear (state-) majority ownership, Telenor and Statoil. They were both first wholly state owned, and then listed on the NY Stock Exchange for partial private ownership, which inevitably means running them according to market rationality with the government acting as a professional commercial owner. Privatization and market participation also means a more visible exposure of commercial risks in public budgets. In addition to this, a part of the Norwegian state's ownership of Statoil has been placed in a separate corporation fully owned by the state, with the sole function of managing the ownership of Statoil. The Norwegian state's revenue from oil and gas production has for some years now been placed in a state- 
owned (sovereign wealth) fund, the Norwegian state's pension fund. It is the second largest sovereign wealth fund in the world, with a capitalization of approximately 3,000 million Norwegian krone (GBP£320 million) (2011). The Santiago-principles, or 'Generally Accepted Practices and Principles for Sovereign Wealth Funds' (GAPP), are applied by the fund. The annual use of the fund (by the state) is set at a standard rate of 4 per cent, return on investment. Both the fund and the state's ownership in Statoil and Telenor underscore the close interaction and interdependence between public and private law and their respective principles and concerns. Both the petroleum and the telecommunication sectors are heavily regulated to ensure the security of production as well as the management of environmental and other hazards. These sectors are also examples of the very close and politically complex interactions between different types of public and private corporations and institutions. They are examples of vital societal infrastructures which require different combinations of corporations and public agencies. Other examples are postal services, railways, energy production, water as public utility, airports etc. Pension policies and funds are another area of complex interdependence between public and private institutions. Changes in the public sector and public law do not lead to its demise, but rather to its differentiation, specialization, and close interaction with private sector actors. Instead of consensus and balancing between the different policy areas there is interaction and interdependence based on differentiation and autonomy. 


\subsection{The regulation of the internet-between public, commercial, and transnational law, and the rights of citizens}

The internet is part of the public sphere and the 'new' civil society but can also probably best be characterized as a public/private hybrid. It includes masses of private exchanges, but in ways which cannot be guaranteed as private. New networks like Facebook are characterized by the same communications being in both the public and private spheres, thereby blurring the boundaries between them. It is international in how it functions, but depends on specific national installations. The internet and its various sub-organizations are networks, but arguably also new types of societal institutions. Public authorities use the internet for both internal and external communications purposes. The regulation of the internet escapes some of the most traditional forms of public regulatory law with their emphasis on control, by its technology dependence and cross-boundary character. It was started by US defense authorities and is not regulated by an international organization in a traditional sense. The user-based ICANN has become the de facto regulator of domain names internationally, albeit with different states having specific agencies which are appointed to manage domain names nationally. ${ }^{19}$

The internet is in its construction primarily technology-driven, but its development and use are influenced by commercial and non-commercial actors alike. New software and

\footnotetext{
${ }^{19}$ Jochen von Bernstorff, 'The Structural Limitations of Network Governance: ICANN as a Case in Point', in Transnational Governance and Constitutionalism.
} 
dataprograms developed by private companies such as Microsoft, Google, Facebook, and Amazon continuously change the ways the internet functions as well as developing new formats for its use. Thus, technological, civil society and commercial dynamics and actors interact closely, albeit in complex and intransparent ways, in the development of the internet, and in how it functions, technologically as well as societally. At the same time it is one of the most vital elements of public communicative infrastructure and the public domain.

Consequently it is on the one hand vital for how the state public sector functions, and on the other hand enabling an increasingly active non-state public sector.

Public law regulates certain aspects of the use of the internet, such as the regulation of ecommerce and trade, criminal law, and the protection of freedom of expression on the internet. Technology changes and commercial actors continuously create new challenges for the legal regulation of the internet in relation to the classic principles and methods of public law. The internet does however hugely support claims for transparency. It has created a form of public sector and new bridges between the public and the private spheres in modern society. It invades our private sphere both with and without our consent, with the potential to have an immense impact on our lives with consequences that are often not considered. The internet invites participation in situations which seem private, but which become, in fact, public. It invites use, with immense access to information on a global scale, but participation leaves traces. It is a continuously changing infrastructure, and we have still not developed a sufficient set of public law principles, guidelines, values, and considerations for its regulation, 
state or non-state. The combination of its accessibility, scope of information, transparency and the vague boundaries between public and private, invites risk, potential for misuse and misconception of its use. It is a new non-state public sphere functioning under conditions of globalization, politically and commercially, and creating complex issue for public regulation, for example in relation to privacy and ethics.

\subsection{The regulation of bio and genetic technologies-between science, markets, politics, law, and ethics}

Another new regulatory challenge for public law and with effects of transcending the public/private distinction is the regulation of the new bio- and genetic technologies which have enabled more intensive and invasive forms of biological and genetic engineering which have great potential but also pose significant hazards and risks for health and the environment. With respect to genetic technologies, there are complex ethical implications and questions concerning human dignity involved. Such technologies are 'global facts' insofar as they are disseminated and used globally in many different societal contexts with quite diverse ethical and political views. They are consequently regulated differently in international and domestic regimes. On the one hand, new biotechnologies are in demand in order to improve food production and the treatment of disease. On the other hand the uses of genetically modified organisms (GMOs) in food and plant production may spread in uncontrolled ways, and have cross-boundary effects with potentially irreversible and damaging consequences for local 
varieties of biodiversity. Genetic knowledge may also create complex ethical dilemmas, and the immediate benefits are not always clear. The use of GMOs, medical biotechnologies, and genetic technologies affect a variety of interests and values, and may have extremely diverse, invasive and uncertain consequences. Technologies are developed in research and commercial facilities. Their application may have positive effects on food production and the treatment of many diseases, but they may also have uncertain, irreversible, ethically dubious, and significant negative effects. Technologies are commercially exploited and thus relevant for trade, but are also objects of risk analysis and further research by the scientific community. The application of different technologies affects the interests and values of a broad constituency including consumers, patients, and farmers. This illustrates the diversity of interests involved in public law regulations and the diversity of relevant substantive considerations, values, and principles.

The dissemination of new biotechnologies is global. Their use is however unevenly distributed, and the views on their relevance politically and ethically diverse. The different economic, environmental and health regulatory regimes which may affect the use of such technologies, collide in different and unpredictable ways. Regulation of the use of new biotechnologies is however to a large extent affected by economic regulation on free movement. The regulatory regimes which affect the use of biotechnologies are both international and domestic, and are frequently uncoordinated. On the international level the most effective public regulatory regimes with relevance also for the regulation of 
biotechnology are the WTO treaties, which include trade in food and medicines but without specific regulation for biotechnology products and health services. The Agreement on Sanitary and Phytosanitary Measures (SPS) regulates sanitary and phytosanitary protection as part of the trade treaty. Risk assessments are used to decide when such protection mechanisms are necessary. ${ }^{20}$ Precautionary measures may be applied, but subject to a reasonable time frame for risk assessment and scientific indications for risk. The Agreement on Trade Related Aspects of Intellectual Property Rights (IPR) (TRIPS) regulates IPR and thus harmonizes regulations for patent rights, including medical patents.

There have been several cases before the WTO Dispute Settlement Bodies (DSB) concerning the use of new biotechnologies in food, in particular $A B$ report WT/DS 26/98 EC-Hormones and Panel report WT/DS 291-293/2006 EC-Biotech. In both cases the panel or the Appellate Body found in favour of the states applying the technologies in question because they did not find sufficient reasons, in the form of scientific evidence for hazards, for the ban on the import of hormone-treated meat and biotech food into the EU. ${ }^{21}$ Precautionary measures were limited to temporary measures, and ethical considerations per se

\footnotetext{
${ }^{20}$ Joseph H. H. Weiler (ed.) The EU, the WTO, and the NAFTA: towards a common law of international trade; Thomas Cottier and Daniel Wüger, Genetic engineering and the world trade system: World Trade Forum, (Oxford: Oxford University Press, 2008); Oren Perez, Ecological sensitivity and global legal pluralism: rethinking the trade and environment debate; Francis Fukuyama, Our Posthuman Future: Consequences of the Biotechnology Revolution, (New York: Farrar, Straus and Giroux, 2002).

${ }^{21}$ Inger-Johanne Sand, 'The legal regulation of the environment and new technologies' (2001) 22(2) Zeitschrift für Rechtssoziologie 169.
} 
are not part of the regulations, with the exception of ordre public considerations. ${ }^{22}$ Under EU law the economic regulations are similar, but the EU goes further in substantive harmonizing regulations, with precautionary measures, concerning GMOs and aspects of medical biotechnology, such as Directive 2001/18/EC of the European Parliament and of the Council of 12 March 2001 on the deliberate release into the environment of genetically modified organisms, (repealing Council Directive 90/220/EEC [2001] OJ L 106/1), and Directive 98/44/EC of the European Parliament and of the Council of 6 July 1998 on the legal protection of biotechnological inventions [1998] OJ L 213/13. The EU has argued for changes relating to measures taken pursuant to the precautionary principle so that longer periods of time can be used for further research in cases where there are indications of scientific evidence for hazards. This is exemplified in the two cases referred to above decided by the Panel and the Apellate Body of the WTO DSB. The two cases resulted in extensive reports which should be seen as examples not only of trade law, but also of public international law. The main structural constraints for consideration of the issues is that of trade law, as follows from the WTO treaties, but the cases are a good illustration of just how entangled different legal and policy areas become, and the problems created by the lack of sufficient international regulation under the WTO umbrella concerning health and environmental protection as well as the omission of ethical considerations from the regime. The examples illustrate the lack of heneral principles in public international law, and its dependence on the specific treaties.

\footnotetext{
${ }^{22}$ Cf Report from ILA Committee on Biotechnology, chair Thomas Cottier, (Hague, 2010).
} 
Another example of the implications of WTO law on the use of medical biotechnology is the effect of the TRIPS agreement and the harmonization of patent regulations on the production of medicines. Costly medicines may be too expensive for less-developed states. The production and the costs of HIV medicine is an example in point. The great need for such medicines in South Africa and Brazil led first to court cases and then concessions from the international pharmaceutical companies for the production of cheaper such medicines in Brazil for use in poorer and less developed states. ${ }^{23}$

There are however several international (soft law) declarations under the auspices of the United Nations Educational, Scientific and Cultural Organization (UNESCO) concerning the regulation of biotechnology and bioethics: the Universal Declaration on Bioethics and Human Rights (2005), and the Universal Declaration on the Human Genome and Human Rights (1997). They include bioethical principles but are not part of sanctionable regimes. With their emphasis on bioethics and on ethical considerations more widely, they illustrate a different type of public international law than the trade treaties. The regulation of medical biotechnology is primarily done on a national basis. In particular, the regulation of reproductive techniques and prenatal tests are culturally and ethically sensitive, and what is and is not allowed, varies significantly even among states which share many cultural values

\footnotetext{
${ }^{23}$ Gunther Teubner and Andreas Fischer-Lescano, 'Regime-Collisions: The Vain Search for Unity in the Fragmentation of Global Law'; Boaventura de Sousa Santos and César Rodríguez-Garavito (eds), Law and Globalization from Below: Towards a Cosmopolitan Legality, (New York: Cambridge University Press, 2005).
} 
and traditions. The Convention on Biological Diversity (CBD, UNEP, 1992) and subsequent Cartagena Protocol on Biosafety (UNEP, 2000) are more specifically and operatively formulated in terms of rights, and refer to international courts, including access to genetic resources on mutually agreed terms and prior informed consent, and access to and transfer of technology. Precaution, sustainability, and ethical considerations are insufficiently dealt with in these conventions even if protection of biodiversity, access to genetic resources, and sharing of technologies are their main goals.

The themes and examples referred to in this section illustrate on the one hand, how public international law is lacking in general principles and fragmented and diverse in its different disciplines and treaties, and on the other hand, how the same treaty themes are deeply entangled and interdependent in how they function. The examples also illustrate the immense diversity with regard to objects, considerations, and values of public law, and the unavoidable conflicts of law within the framework of public law.

\section{Conclusions: What is Public Law under Conditions of}

\section{Globalization?}

The substance, the principles, the procedures, and the institutions of public law mirror society, the practices and the regulation of power, and the relations between actors. Public law is an expression of power, and it regulates power. Public law has been a quintessential feature of 
the infrastructure of modern nation-states. It is difficult to conceive of states without public law. Both the processes of globalization and the increasing functional and communicative differentiation, of politics, law, economics, science and their may operative sub-systems, have led to significant changes and an increased diversity of the themes, procedures, concepts, and institutions of public law, and the concept of the public. ${ }^{24}$ The wide variety of objects and themes of public regulation indicate an equivalent variety of public agencies, procedures, and principles. Society, and thus also the public sphere, has become increasingly communicatively and institutionally differentiated by the differentiation of politics, law, economics, science and their many organizational sub-systems. It is therefore less clear whether and how 'the common good' can be defined. It has been said that public law has moved from disciplining a repressive state, to regulating a variety of new technologies. ${ }^{25}$ Conflicts concern citizens and technological regimes as much as citizens and the state. Technologies are treated mores as given facts, and not as political or accountable institutions. Inter- and transnational institutions have become part of political and legal decision-making, but they are not always democratic nor held accountable. They stand in a different relation to the citizens than the state. How political decisions are made, and how consensus and compromises are reached, are different on a global or international basis from that of the domestic level not only in terms of different

\footnotetext{
${ }^{24}$ Niklas Luhmann, The Differentiation of Society; Risk: A Sociological Theory.

${ }^{25}$ Gunther Teubner, 'The King’s Many Bodies' (1997) 31 Law and Society Review 763; Gunther Teubner, 'Societal Constitutionalism'.
} 
politico-legal regimes, but also because they refer to a much more culturally heterogeneous foundation.

The consequences for public law of these changes concern many of its qualities. We need to ask what is society,, and, what is the public in society, under conditions of globalization. We need to look into what the functions of public law are, what its institutions are, how they can be legitimized, and how rule-of-law institutions can be upheld under more legal pluralistic and societally complex situations. Three types of consequences can be pointed to here: first, globalization and various forms of multi-level governance will have consequences for the forms and the procedures of democracy in the creation of public law and thus also of its legitimacy. Decision-making on the international level will imply more indirect democratic participation. It may involve significant compromises. It may also mean a more specialized, sectorized, and at times technocratic institutional decision-making process. On the other hand, international treaties and organizations have the potential to include cross-boundary problems and dynamics in ways nation-states cannot, and thus have the potential to respond more realistically to a wider democratic polity in relation to current problems even if procedures are more indirect and complex.

Secondly, the themes and problems of public law are changing at both the domestic and the international levels to those of a more liberal economy and to the regulation of a variety of technologies. Several regulatory areas exemplify the changes, the transcendence of the public/private divide, and the institutional consequences involved. Public economic regulatory 
regimes are focused on creating fair conditions for competition, liberal markets, and free movement. A well-functioning market economy is seen as vital also for macro-economic purposes. In liberal market theories there are close connections between micro- and macroeconomics. Liberal rights are seen as the basis for a functioning economy. Free-movement regulations and competition law, such as in the EU, are however in effect quite intricate and detailed regulatory regimes. Even liberal rights have to draw boundaries between them and various forms of social protection. Domestic public regulations in a liberal economy apply a variety of market-oriented mechanisms which are also exemplary of the transcendence of the public/private divide including public procurement, privatization of services, state-owned corporations, benchmarking, evaluation, certification, and accreditation. State-owned corporations and public pension funds are good examples of the fusion between corporate, private, and public economics, and of the links between public and private accountability, and between social and economic responsibility. ${ }^{26}$ By way of illustration, the Norwegian Pension Fund (based on petroleum taxes and income) depends on oil and gas prices, the international stock market, and the public regulatory regimes of many states, but is also a vital public asset and operates according to public economic and legal standards. The internet has become the most vital communications infrastructure, and is public and private at the same time. Created by US defense authorities, it functions as a common utility defined by its technologies and

\footnotetext{
${ }^{26}$ Inger-Johanne Sand, 'Changes in the organization of public administration and in the relations between the public and the private sectors. Consequences of the evolution of Europeanisation, globalisation and risk society'.
} 
uses. It is a technology network used by public and private actors. Its domain-name (and organizing) company is ICANN, a non-governmental organization, which cooperates with governmental advisory committees. Certain aspects of internet use are regulated by public authorities, but the impact of the internet must primarily be explained by its technology and the potential for use created by this. The regulation of the use of new bio- and genetic technologies is another example of a social issue and accompanying legal regulation transcending the traditional boundaries between public and private. Some of the main problems of current regulations concern complex risk assessment and ethical problems. The risk assessment relies heavily on specialized science. The ethical issues transcend public/private distinctions, discourses, and values. Both the internet and new biotechnologies are technologies with significant effects on society, also ethical, creating new institutions beyond the state and classic public law institutions. They require public law regulation. The autonomy of technologies does however pose challenges for legal interventions. ${ }^{27}$

Thirdly the regulatory challenges are now global, technological, risk-oriented, ethical, and involve the transcendence of public/private law distinctions. New technologies, their global use and exploitation, an increased focus on human rights, and more intensive combinations of public and private law mechanisms have produced complex regulatory themes which have extended the boundaries of public law and how we think about it. Public

\footnotetext{
${ }^{27}$ Teubner and Fischer-Lescano, 'Regime-Collisions'; Gunther Teubner, Hans Lindahl, Emilios Christodoulidis and Chris Thornhill, 'Constitutionalising Polycontextuality' (2011) 20(2) Social and Legal Studies 209.
} 
regulations are increasingly formulated in more heterogeneous social, cultural, and political contexts. The new regulatory themes and their global context have led to the emergence of new regulatory concepts, standards, and principles, or to a renewed focus on certain concepts. Substantive regulatory concepts are needed in order to formulate a baseline of human rights protection, environmental and health protection, and some forms of social protection. Several such concepts have been formulated, but they are still too vague, too indeterminate, and insufficiently developed. Some of these concepts include human dignity, precaution, health safety, sustainability, biodiversity, generational justice, and ethical standards. These are vital concepts, but they need to be more precisely defined and more robustly interpreted, particularly in relation to economic standards. At the same time public law is still essentially defined by the classical procedures and principles of modern democratic societies, such as the rule of law, objectivity, rationality, impartiality, transparency, and participation, in addition to democratic participation and legitimacy mentioned earlier. Additionally proportionality may be used to provide context to particular functional aims as well as define the relationship between various goals. Further reflection on the use and development of both the newer and the more classical concepts is a vital issue for further research in public international as well as domestic public law. 